\title{
Status, Importance and Major Issues in Water Source in Watershed of Chitwan, Nepal
}

\section{Prerana Shrestha $^{1 *}$, Bikram Manandhar ${ }^{1,2}$, Nabin Dhungana ${ }^{3}$ and Sujan Rajbhandari ${ }^{4}$}

Abstract: Khageri Khola sub-watershed of the Chitwan district is stressed by climate change and is facing changes in its water source. The main objective of this study was to assess the status of water sources, their importance, water source issues, and distribution of water sources as well as to suggest appropriate conservation and management measures. Various participatory tools such as household interviews, focus group discussions and stakeholder's consultations were used. In total, 56 water sources were identified in eight micro-watersheds in Khageri Khola sub-watershed. The overall water sources were found decreasing with moderate $(43 \%)$ to insufficient (32\%) amount of water available for drinking. People meet their current water demand through tap water (43\%) and tube wells/wells (38\%). Conservation and management measures such as tree plantation, solar planning (solar power for water pumping system) for wildlife, construction of water tanks and bamboo plantation have been adopted. Hence, upstream soil erosion should be reduced to save downstream sources from flash floods by emphasizing land use planning. Regular observation, capital funding for water sources and catchment conservation and awareness programs are further required to minimize the possible risks on water sources.

Keywords: Khageri Khola sub-watershed, water source, climate variability, conservation measures.

Shrestha, P., B. Manandhar, N. Dhungana, and S. Rajbhandari. 2020. Status, Importance and Major Issues in Water Source in Watershed of Chitwan, Nepal. No. 17: page 135 to 154. DOI: https://doi.org/10.3126/forestry.v17i0.33628

1 Tribhuvan University, Institute of Forestry, Hetauda, Nepal

2 University of Chinese Academy of Sciences, Beijing, 10049, China

3 Care Nepal, 4/288-Samata Bhawan, Dhobighat, P.O. Box 1661, Lalitpur, Nepal

4 Division Forest Office, RukumPurba, Nepal

* Corresponding author, email address: preranashrestha26@gmail.com, 


\section{Introduction}

Global temperature has been increasing due to climate change. The Intergovernmental Panel on Climate Change (IPCC) has also stated that with the continuation of prevailing activities the warming might be 3.7 to $4.8^{\circ} \mathrm{C}$ (IPCC 2014). Water, a natural resource found and used widely in the natural environment, is diminishing day-by-day (Singh et al. 2019). Impacts of climate change have an effect on water resources such as water supply, its demand and resource availability (Nicol and Kaur 2009). The diminishing fresh water availability may have serious effect in people's livelihood and different sectors like: food security, industrial growth and environmental sustainability all over the world (WWF 2006). $40 \%$ of people of developing countries are deprived of clean drinking water (UN 2018; WHO 2018). Water-induced impacts on agriculture, health, and incomes may cause decline in the growth rates by as much as 6\% of GDP by 2050 in some regions such as Central Africa, East Asia, Middle East and the Sahel in Africa (WBG 2016). Hence, Nepal cannot remain untouched by this global phenomenon (Lamichhane and Awasthi 2009). In Nepal at highest, temperature is increasing at the rate of $0.02^{\circ} \mathrm{C} /$ year, mainly during the monsoon season (MoFE 2019). Despite having vast water resources, Nepal has been ranked among top five countries for poor drinking water systems where most climate impacted sectors are water resources and hydropower (OECD 2003). Fresh water is unevenly distributed in Nepal. The complex geography has been one of the factors hindering the supply of water services in rural area (Gurung et al. 2019). Construction of water tanks has become expensive or forbidden in settlements which are beyond the reach of natural source or are located in deep gullies and valleys (Sharma et al. 2016). However, degrading water quality owing to contamination with bacteria, sediments and suspended solids has also created water scarcity even to the people settled near water source (Sharma et al. 2016). In Nepal, water is seriously scarce with increasing issues related to water quality (Merz et al. 2003). Mid-hills and high-hills are found to have severe water scarcity (Gurung et al. 2019). Despite numerous water resources, the mountains and hills of Nepal have $80 \%$ of the 13 million people who depend on spring water as the primary source (Tambe et al. 2012). Most population of the Terai rely on ground water to fulfill their daily requirement (Malla and Karki 2016). The Terai region has already experienced numerous extreme weather events and frequent devastating floods (MoFSC 2015). According to climate vulnerability mapping in Nepal, Chitwan district having vulnerability index from 0.601 to 0.786 is one of the highly vulnerable zones (MoE 2010).

The Chitwan district has been influenced by various precipitation patterns and increased temperature (Dhungana 2019). Water scarcity is caused by the gradual decrease in number and quality of water resources. Hence, for understanding biophysical, socioeconomic, and institutional settings, various qualitative and quantitative researches are required for water related issues (Poudel and Duex 2017). For past few years, fluctuation in rainfall pattern, too little in winter leading to drought or too much in monsoon, leading to flash flood, unsustainable development of the infrastructure, forest encroachment, deforestation and forest degradation have 
resulted in drying of water sources and decreasing quantity also in Khageri Khola sub-watershed (DSCO 2017). In Khageri Khola sub-watershed downstream people's livelihood, agriculture, tourism, biodiversity highly depend on water flowing from the upstream area, which also supplies water to the Khageri irrigation project, wildlife of Barandabhar corridor, water sources and wetland birds in the Bishazari Tal, Ramsar site which also has ecotourism benefits (DSCO 2017). The main objective of this study was to assess the status of water sources, their importance, issues, and distribution. The study also identified further impacts of climate change and suggested appropriate conservation and management measures.

\section{Materials and Methods}

\section{Study Area}

Khageri Khola sub-watershed is located in Chitwan district of Bagmati Province. It

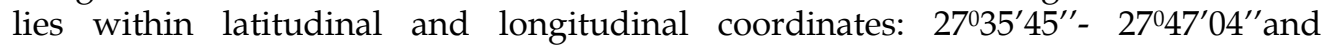
$84^{0} 27^{\prime} 37^{\prime \prime}-84^{0} 35^{\prime} 06^{\prime \prime}$ respectively. The mean annual temperature is 0.04 degree Celsius and annual rainfall trend is 11.34 milimeter (mm) (Practical Action 2009). Increasing trend in annual minimum temperature in post monsoon was observed in Chitwan (Practical Action 2009). It is a critical sub-watershed which feeds water to Gandaki River basin through Rapti River. It lies in the Upper Siwalik and Inner Terai (Dun Valley) in Northern and Eastern fringe of the Barandabhar forest corridor on both sides of the Mahendra Highway. The study area has altitudinal range from $180 \mathrm{~m}$ to $1307 \mathrm{~m}$ above sea level. The sub-watershed spreads in $133 \mathrm{sq} . \mathrm{km}$ area out to ward number 7 of Ichhakamana Rural Municipality, ward numbers 8, 9, 10, 11 \& 12 of Ratnanagar Municipality, ward numbers 1, 2, 3, 4, 5, 6, 7 \& 8 of Kalika Municipality and ward numbers 1, 8, 11, 12 \& 29 of Bharatpur Metropolitan. The sub-watershed is divided into 8 micro-watersheds (DSCO 2017).

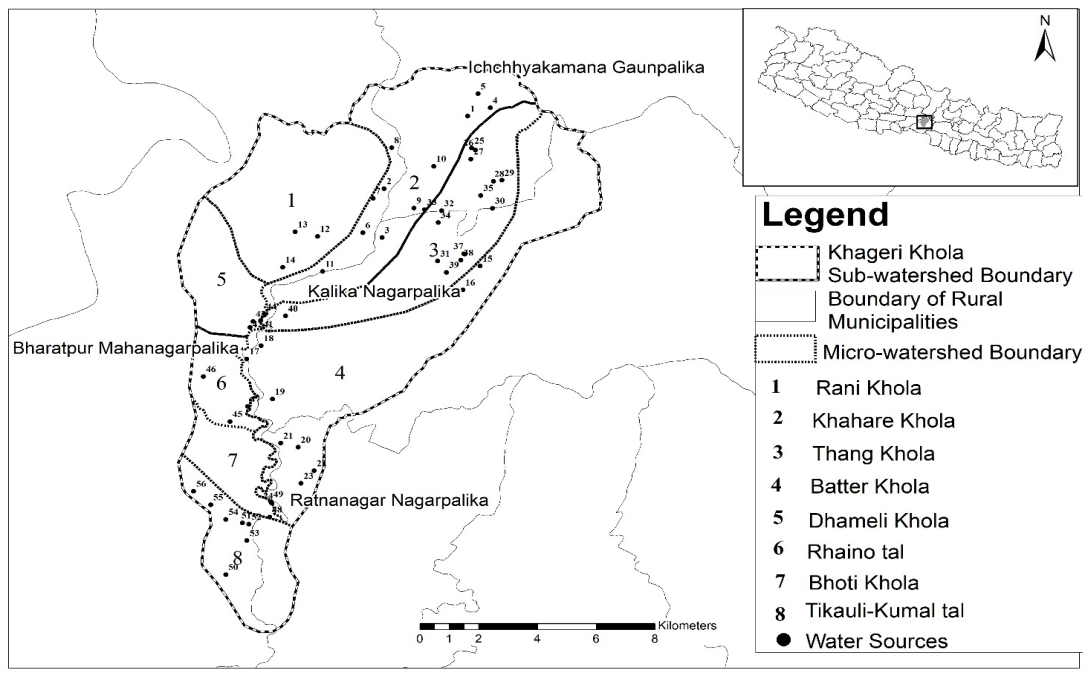

Figure 1: Location map of Khageri Khola sub-watershed

(Note: The number shown in the figure represent name of the water source in Annex 1 in Khageri Khola sub-watershed) 


\section{Methods}

\section{Data Collection}

The study was built on the primary data collected by using participatory rural appraisal (PRA) tools. The primary data were collected for identifying the water source, major issues of water source and their status. People's perception of climate variability was also determined to gain a better knowledge of climate change. A preliminary survey was conducted to identify the general features and existing situation of the study area. Consultation with upstream and downstream communities was done to build a common understanding of the study area followed by participatory water resources mapping. Household questionnaire survey was conducted with 370 households (HHs), i.e., 10\% out of total 3,686 households inside sub-watershed (DSCO 2017), using simple random sampling techniques. Likewise, five focus group discussions (FGDs) guided by a set of checklist were conducted with the Community Forest User's Groups (CFUGs) of the sub-watershed area (Table 1) for preliminary mapping and to better know the situation of water source. The key informant interview (KII) was done with local leaders, individuals affiliated with NGO's: Hariyo Ban Program and Government Officials for in-depth information about the water sources. This study has also used raw climatic data of Rampur station obtained from the Department of Hydrology and Meteorology, Kathmandu, Nepal, which have been used in the management plan of the sub-watershed (DSCO 2017), for 35 years from 1981 to 2016 showing increasing trend of mean annual rainfall, mean maximum temperature and mean minimum temperature. Then they were compared with the community perception obtained during the survey on the average rainfall and temperature now compared to 35 years ago to determine the climate variability.

Table 1: Participant of CFUG for FGDs

\begin{tabular}{|c|l|c|c|c|}
\hline S.N. & \multicolumn{1}{|c|}{ Location of FGD } & Total participants & Male & Female \\
\hline 1 & Chaturmukhi CFUG & 8 & 5 & 3 \\
\hline 2 & Bhimwali CFUG & 11 & 5 & 6 \\
\hline 3 & Shree Chandinath CFUG & 10 & 6 & 4 \\
\hline 4 & Tinkanya CFUG & 10 & 4 & 6 \\
\hline 5 & Tikauli buffer zone CFUG & 6 & 3 & 3 \\
\hline & Total & $\mathbf{4 5}$ & $\mathbf{2 3}$ & $\mathbf{2 2}$ \\
\hline
\end{tabular}

\section{Data Analysis}

The data (both primary and secondary) collected from the HH questionnaire survey, FGDs, KIIs, field observations and review of secondary sources were both qualitative and qualitative in nature. These data were analyzed using Ms Excel and other 
participatory tools and techniques. The water source map was prepared using participatory tools (participatory mapping), field verification and recording global positioning system (GPS) locations. The water sources mapping was done using Arc Map 10.3. The trends of temporal variation of temperature and precipitation were analyzed using linear regression. The linear trends between time series and climatic data are as given in equation below:

$\mathrm{Y}=\mathrm{a}+\mathrm{bx}$,

Where, $\mathrm{y}=$ time (year), $\mathrm{x}=$ temperature or precipitation and "a" and "b" are constants.

\section{Results and Discussion}

\section{Socio-Demographic Information of the Respondents}

Among the surveyed 370 households, the majority of respondents were females $(52 \%)$ and between 30 and 44 years of age (Table 2). Most of the respondents were Janajati followed by Brahmins and Chhetri. Castes like Dalit and Thakuri were less in numbers. A majority of (32\%) respondents were involved in agriculture, followed by government and private services. In Chitwan 251,000 ha of land is agricultural land, making agriculture essential sector for the economy (Malla and Karki 2016). The education status of the respondents ranged from illiterate to graduate level with illiterate being dominant. The involvement of the adult age group with a wide range of education and high representation of females made our study more comprehensive (Table 2). The reason behind high representation of females in our household survey was that a majority of males were at work in the farms or in private services during the survey.

Table 2: Socio-demographic information of the respondents

\begin{tabular}{|c|c|c|}
\hline Particulars & Group & $\begin{array}{c}\text { Percentage of the } \\
\text { respondent }(\mathbf{n}=\mathbf{3 7 0})\end{array}$ \\
\hline \multirow{3}{*}{ Gender } & Male & 48 \\
\cline { 2 - 3 } & Female & 52 \\
\hline \multirow{4}{*}{ Age } & $25-29$ years & 13 \\
\cline { 2 - 3 } & $30-44$ years & 42 \\
\cline { 2 - 3 } & 45-60 years & 30 \\
\cline { 2 - 3 } & 60 years or older & 15 \\
\hline \multirow{3}{*}{$\begin{array}{c}\text { Literacy and } \\
\text { education }\end{array}$} & Illiterate & 46 \\
\cline { 2 - 3 } & Under SEE & 41 \\
\cline { 2 - 3 } & Higher secondary & 9 \\
\cline { 2 - 3 } & Graduate & 4 \\
\hline Caste & Brahmin/Chhetri & 35 \\
\hline
\end{tabular}




\begin{tabular}{|c|c|c|}
\hline \multirow{4}{*}{ Primary Occupation } & Janajati & 38 \\
\cline { 2 - 3 } & Dalit & 15 \\
\cline { 2 - 3 } & Others & 12 \\
\cline { 2 - 3 } & Agriculture & 32 \\
\cline { 2 - 3 } & Business & 9 \\
\cline { 2 - 3 } & Government services & 20 \\
\cline { 2 - 3 } & Private services & 27 \\
\cline { 2 - 3 } & Foreign employment & 12 \\
\hline
\end{tabular}

Water Sources, Their Status, Importance and Major Issues in the SubWatershed

The whole sub-watershed area is divided into eight micro-watersheds (Figure 1). Altogether 56 water sources were located in the Khageri Khola sub-watershed (Figure 1 and Annex 1). In Khageri Khola sub-watershed, water sources that have less than sufficient amount of water have been observed. Out of them most are diminishing and drying up. Out of the eight micro-watersheds during field observation, Thang Khola and Khahare Khola micro-watersheds have highest number of water sources whereas Bhoti Khola micro-watershed has the lowest. In Khahare Khola micro-watershed, encroachment, deforestation and soil erosion have led it to be the most critical micro-watershed. Khahare Khola and Thang Khola are the important micro-watersheds as they have gradually decreasing feeding streams which provide water to upstream and downstream sources. However, population is rapidly increasing in the downstream area, leading to competition on the limited resources (Dhakal 2018). Communities of downstream involved in agriculture are at risk to water-related disasters (Mallick et al. 2019). However, in Batter Khola and Rhino Tal artificial ponds like mini Rhino Tal and Panchpokhari Tal for irrigation have reduced stress on the water source. Among the identified water sources, Mulsyangdhi Khola, Amilipani Muhan, Bung Khahare Khola, Khahare Khola, Amilipani Muhan, Tirtire Dhara, Batter Khola, Thulosyangdi, Sano Syangdi Khola and Bhoti Khola are the major sources as they are the feeding sources to other water sources upstream and downstream. Community people have observed that many perennial water sources, even in monsoon, are facing a gradual decrease in the amount of water as compared to the past 35 years. In Chitwan district (Malla and Karki 2016), ground water level had declined in the pre-monsoon season (April) where people were compelled to use shallow groundwater, whereas in the postmonsoon season levels remained moreover constant (October). Mallick et al. (2019) have also stated that urbanization in upstream areas like Padampur, Chitwan district has increased since 1998, causing diversion of water to other systems and affecting water availability. Chapagain et al. (2017) also found that in mid-hill spring discharge has decreased by $30 \%$ over the last 30 years. Nepal et al. (2018) have also confirmed increasing spring dryness and seasonal behaviour, and reduced discharge over 50 years in the mid-hills of Hindu Kush Himalaya (HKH) region. 
Water sources of the Khageri Khola sub-watershed are utilized by local people for drinking, household chores, irrigation as well as by wildlife (Dhakal 2010). Based on people's perception, climate variability like rising temperatures and erratic rainfall pattern with forest encroachment, deforestation, illegal felling, urbanization and open grazing, open water sources resulting in soil erosion and land degradation upstream, followed by riverbank cutting and sedimentation downstream were the issues that contributed (Dhakal 2010) to decreasing water sources (Annex 1). Sedimentation on the flood plain can be beneficial if the sediment is fine and fertile, but can be destructive if sandy sediment is deposited on fertile farm-land turning the latter into useless fallow land and thereby threatening the livelihoods of small land holders and farmers (Flügel et al. 2018). Likewise, Malla and Karki (2016) have reported that anthropogenic systems in the Chitwan district like population growth, urbanization, agriculture, and tourism have degraded the groundwater environment causing change in land use as well as agricultural cropping patterns and practices. The Ratnanagar municipality has also built temporary dumping sites inside the Panchakanya CFUG which has indirectly polluted the water of the Khageri Khola at Ratananagar Municipality-11 (DSCO 2017). Studies based on people's perception have assigned the drying of springs to increasing temperature (Pandey et al. 2018) and the late onset of rains, erratic rainfall patterns (Macchi et al. 2015) and degradation of forest (Pandey et al. 2018). Major causes for land use change were found to be the construction of the east west highway, population growth and the resettlement program from Padampur VDC, Chitwan district (Dhakal 2010). However, in past decades environmental concerns about such structures had increasingly gained attention as well (Flügel et al. 2018). Water hyacinth along the river sides and Banmara, that pollutes the water, bitter vines and Nilogandhe have impacted water source quality and area shrinkage in water holes, Tal and the forest ecosystem. The presence of water hyacinth in Ghol and Lake whole year (Burlakoti and Karmacharya 2004) specify subsequent pollution of groundwater recharge. The Tal area in Bharatpur Metropolitan city- 8 is also being occupied by alien plant species which is impacting animals and birds that depend on wetland area (DSCO 2017). Bhimoli Park Khola and Farmban Khola are the rivers which lie inside the Bhimoli Park separated from human settlement for aesthetic value but they usually dry up during the summer season. In mini Rhino Tal, Gunumandre Ghol and Thulo Ghol- artificial pond, solar water pumping systems were used during dry season, which has been beneficial for wildlife. Panchpokhari Khola and Panchakanya Irrigation project (Shrestha et al. 2017) and Khageri Irrigation Project (Malla and Karki 2016) have managed water for drinking purpose and irrigation. The status of water sources, their importance and major issues have also been shown in Annex 1.

\section{Source of Drinking Water in Sub-Watershed}

Majority of the people extracted water from the spring/mul $(35 \%)$ and well/tube well (30\%) 35 years ago (Figure 2). While in the present situation majority of them (43\%) extract water form tap and well/tube well (38\%). Malla and Karki (2016) have also reported that groundwater has been one of the major sources of 
drinking water supply for the Bharatpur Water Supply Management Board (BWSMB) as well as other parts of the Chitwan district. Similarly, Shrestha et al. (2017) have also reported that in Panchakanya Irrigation System area well water was mostly used, which now has shifted to tap water. People had sufficient water earlier but had difficulty in fetching water. In contrast, now it has been easy for women and children to fetch water but it is not available readily especially in the dry season in some areas, including Tikauli-Kumal Tal micro-watershed. Chaudhary (2020) has also reported that water is distributed through taps in Badarjhula, Chitwan district where two reservoirs of drinking water were found polluted due to floods and sediments. In these areas, people still have to fetch water from other distant sources such as springs $(15 \%)$ and rivers $(4 \%)$ which are also diminishing compared to past years. The study by Gurung et al (2019) also shows that inspite of tap water being the main source of drinking water to $72 \%$ of the households in the hilly region, the people had to depend on other natural springs. Furthermore, the study by Singh et al. (2019) has also stated that during dry periods spring water reduces villagers' reliance on stream water to meet their demands. The sub-watershed management plan (DSCO 2017) has also shown that the communities mostly used tap and well water now. It was found that pipe water was used in all seasons, while ground water was mostly used during pre-monsoon and in winter.

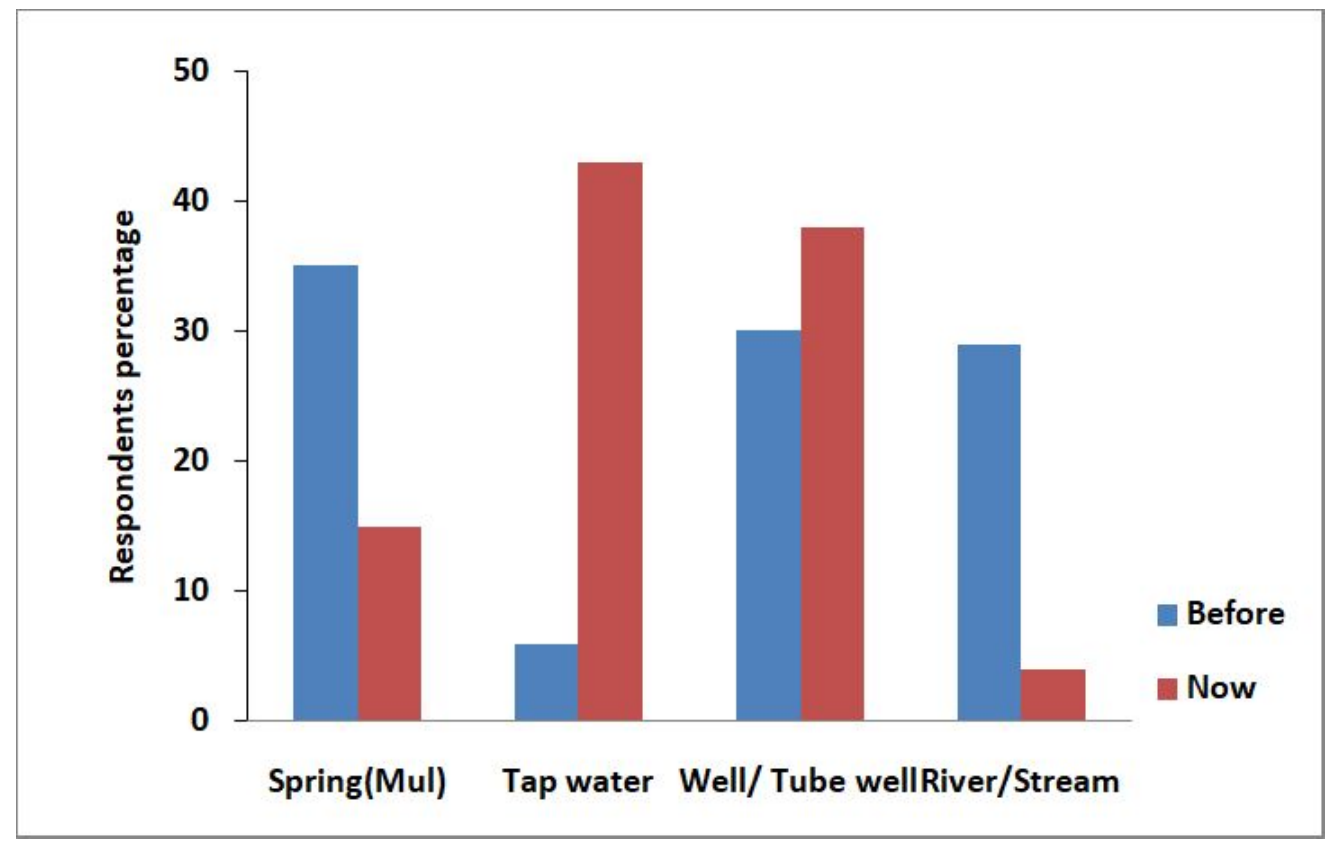

Figure 2: Source of drinking water in sub-watershed 


\section{Current Situation of Water Sources in Sub-Watershed}

Among the households surveyed, for past 35 years overall water sources were found decreasing in the current situation (Figure 3). Very few of them said that water source was decreasing and/or constant, which might be due to their lack of awareness about the decreasing water sources and diminishing interest in the natural resources. During the field visit and survey, it was observed that changing climatic patterns along with landslide, soil erosion, community settlement in upstream and sedimentation, invasive species, increasing population, urbanization in the downstream were affecting the water source in the sub-watershed. A similar result of decreasing dry season flow in Pampa Khola of the Chitwan district was reported by the villagers (Shukla et al. 1997). In the dry season, the flow of many water sources of Khageri Khola sub-watershed like Khahare Khola, Amilipani Muhan and Lipegauda Muhan was decreasing and many springs like Farm ban Khola dried up. Similarly, ICIMOD (2015) also suggests that, during the last decade, 15 to 30 percent of springs have dried up in two mid-hill watersheds in Nepal.

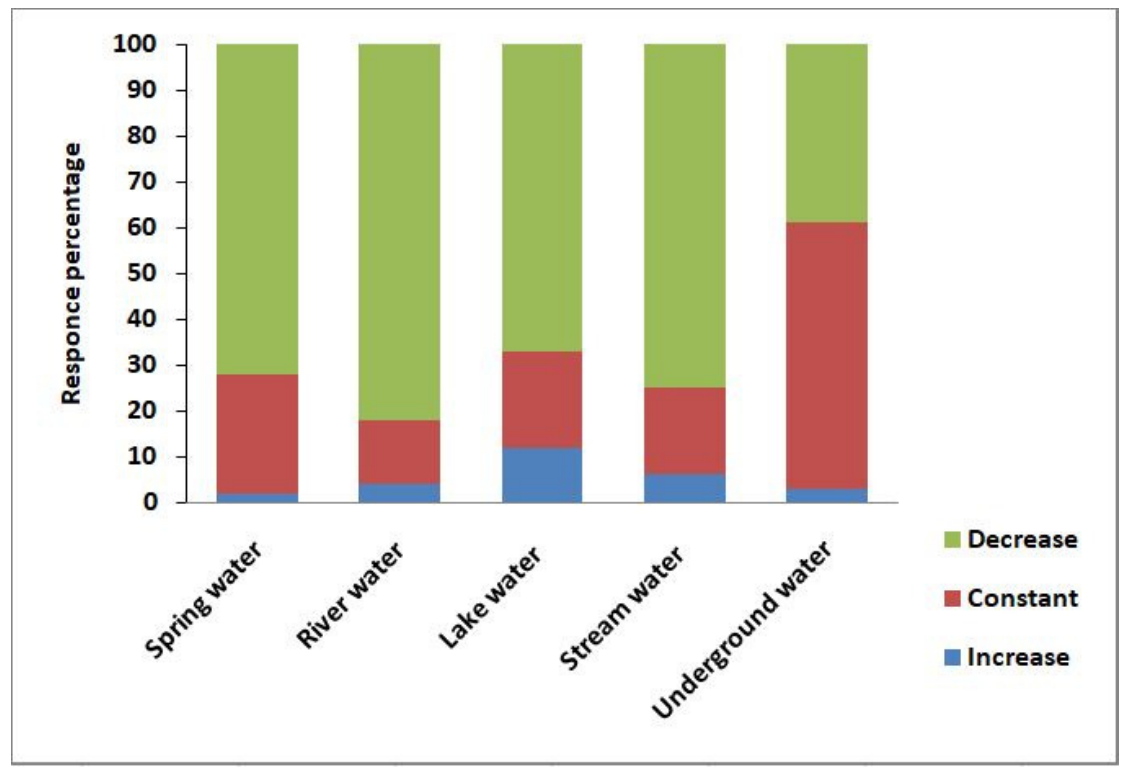

Figure 3: Current situation of water source in sub-watershed

\section{Drinking Water Availability in Sub-Watershed}

The water availability in the sub-watershed was sufficient (45\%) 35 years ago (Figure 4). But now people are facing problems in water availability. People have been managing water through alternate water pipe distribution, well water and tank water to achieve moderate amount of water for their daily household chores. Poeple directly dependent on water source like spring and river have insufficient amount of water. As in the past, most of the water sources had sufficient amounts of water which, due to climatic variability, increase in drought, dryness, river bank cutting 
and conversion of land use to settlement (DSCO 2017), has gradually decreased. Decreasing precipitation in the dry season also has impact on groundwater recharge (Gurung and Bhandari 2009). Usually in the dry season, water is not sufficient for people in the sub-watershed and they are facing water scarcity. Similary, in Badarjhula, Chitwan district, daily requirement of water for drinking and irrigation has been more affected than in past years by the drying up of river flow and groundwater (Chaudhary 2020). Water supply in partially irrigated area of Chitwan district is insufficient in other seasons while it remains sufficient in the monsoon season (Thapa 2005). The study by Sharma et al. (2016) reported that for most households of Tinpiple and Dapcha in the Kavrepalanchok district, water from all accessible sources was insufficient and diminishing each year to meet their household requirements. The earthquake in Nepal (2015) also had an immense and immediate impact in the Melamchi region where the water volume of springs has dried by 18 percent (Chapagain et al. 2017).

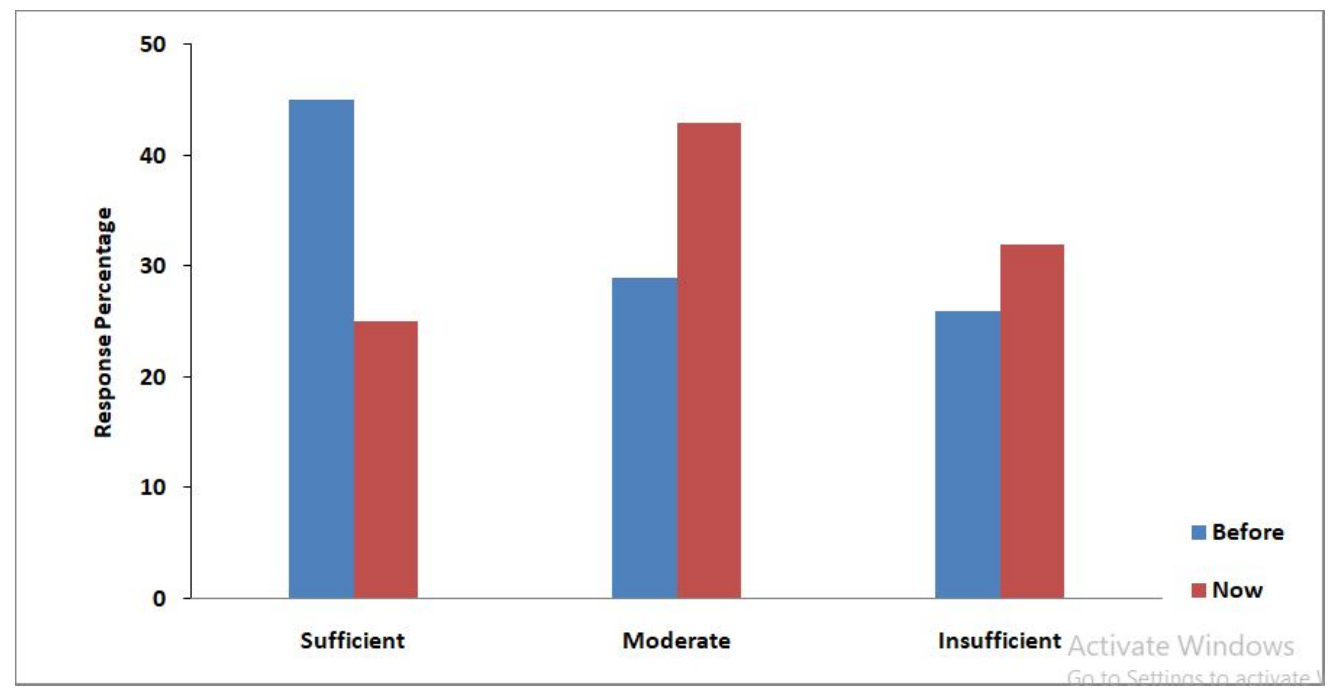

Figure 4: Status of drinking water availability in sub-watershed

\section{Community perception on impact of climate change on water sources}

As stated by Intergovernmental Panel on Climate Change IPCC (2007), at least 30 years of data of climatic variables are suggested to study climate change, so more than 30 years of data were used for the trend analysis. The average annual temperature of Rampur station (i.e. nearest station from the study area) has increased during the past 35 years (Annex 2). Maximum and minimum mean temperature has increased at the rate of 0.0033 degree Celsius and 0.0204 degree Celsius each year respectively (Annex 2). Likewise, mean annual rainfall has increased (Annex 2) at the rate of $1.7413 \mathrm{~mm}$ per year but its nature was found erratic as its pattern, intensity and season were irregular (DCSO 2017). Similarly, $88 \%$ of the respondents in the sub-watershed reported that the average temperature of sub- 
watershed is increasing and that rainfall is decreasing (95\%) with change in intensity, pattern and seasons compared to past 35 years (Table 3 ).

Table 3: Community perception on climate variability

\begin{tabular}{|l|c|c|c|}
\hline Perception of people towards Climate variability & $\begin{array}{c}\text { Increase } \\
\text { (\%) }\end{array}$ & $\begin{array}{c}\text { Constant } \\
\text { (\%) }\end{array}$ & $\begin{array}{c}\text { Decrease } \\
\text { (\%) }\end{array}$ \\
\hline $\begin{array}{l}\text { Average temperature now compared to 35 years } \\
\text { ago }\end{array}$ & 88 & 12 & 0 \\
\hline Average rainfall now compared to 35 years ago & 0 & 5 & 95 \\
\hline $\begin{array}{l}\text { Number of dry days now compared to 35 years } \\
\text { ago }\end{array}$ & 83 & 5 & 12 \\
\hline $\begin{array}{l}\text { Fresh water sources due to climate now compared } \\
\text { to 35 years ago }\end{array}$ & 3 & 19 & 77 \\
\hline $\begin{array}{l}\text { Occurrence of other hazards (e.g. floods, } \\
\text { landslides, erosion, drought etc.) now compared to } \\
35 \text { years ago }\end{array}$ & 86 & 7 & 8 \\
\hline $\begin{array}{l}\text { Presence of invasive species now compared to 35 } \\
\text { years ago }\end{array}$ & 89 & 6 & 4 \\
\hline
\end{tabular}

The intensive monsoon with high total precipitation creates difficulty in sufficient recharge of ground water reservoirs as it leaves the site through surface runoff (Gurung and Bhandari 2009). These patterns of rainfall were perceived to be decreasing by the community people. The temperature and precipitation analysed data (DSCO 2017) were compared to the anecdotal evidence by local people (Table 3). Likewise, Gurung and Bhandari (2009, Pg 93) have reported that total annual precipitation of Chitwan district has been above the national average in the last few years causing extreme precipitation events exceeding $300 \mathrm{~mm}$ in 24 hours. Most farmers settled in Riu and Rapti water basin area attributed climate change to untimely rainfall, drought and relatively high temperature as compared to the past (Regmi and Upendram 2019). Decreasing precipitation in Thulo Khola watershed of Nuwakot district is also affecting the basic requirement of people as drinking water, agricultural production and ecological condition (Poudel and Duex 2017). Rainfall variability in Kathmandu has also caused decline in the yield from spring water sources or disappearance of the whole system (Khan et al. 2013). Due to irrigation shortage, farmers had adapted cash crops and hybrid seeds from grain cultivation to cope with climate change (Khanal and Kattel 2017). Changing climate will eventually increase the requirement of water for irrigation affecting the agricultural planting times. Intense rainfall may lead to increase of erosion and floods especially if they take place where vegetation cover is low (Nepal et al. 2014). 
Seventy seven percent $(77 \%)$ of respondents agreed that fresh water sources were decreasing, causing increased water problems for the people, livestock as well as the wildlife (Table 4). The major impacts of climate change in CF (Community Forest) of the Lamjung district were water sources drying resulting in water shortage, introduction of various disasters like flood, river bank cutting, loss of lives, agricultural production and biodiversity (Dhungana et al. 2020). Occurrence of climate hazards (Table 3) has increased as stated by $86 \%$ of the respondents and invasive species like Banmara, Nilo Gandhe, bitter vine and water hyacinth have been observed in sub-watersheds due to climate variability (Dukes and Mooney 1999).

Landslides have been the dominant natural hazard in the northern part of the subwatershed (Dhakal 2018). As reported by Regmi and Upendram (2019), recurring events of flood and river bank erosion in Riu and Rapti water basin in the Chitwan district were caused by increased erratic and intense rainfall. Similar results of increased temperature and uncertain rainfall magnitude and intensity have affected erosion processes resulting in intensified over-flow often triggering landslides in HKH region (Flügel et al. 2018). Gradual decrease in the water source, change in rainfall patterns and change in land use including climate variability have caused soil erosion in upstream leading to flash floods and sedimentation in downstream in the Khageri Khola sub-watershed. To face the gradual decrease in water availability and different climate variability, conservation and management measures such as water source protection, bamboo plantation to decrease landslide (Thang Khola, Batter Khola and Khahare Khola micro-watershed), water collection tank construction and recharge pond construction have been done. Further, in the downstream area, projects such as Khageri irrigation projects, Panchapokhari irrigation, and solar water pumping in artificial pond like Rhino Tal, Thulo Ghol and Gunumandre Ghol for wildlife have been implemented. Likewise, Dhungana et al. (2020) have also mentioned that bamboo plantation, application of bio-engineering measures (Paudel and Kafle 2012), construction of conservation ponds and planting drought resistant crops are the most successful adaptation measures for livelihood of forest dependent people. Furthermore, adaptation and management activities needed to be done are: appropriate monitoring of sources, awareness programs, river bank protection, landslide treatment, land-use restoration, rainwater harvesting, plantation in degraded and open area water source protection, incentive mechanism for farmers for water source protection, capital funding for water sources and integrated planning for conservation and management of the sub-watershed. Along with this, the forecast system of rain and weather at the national and regional level, advanced technology-based research and monitoring system are urgent to minimize the adverse impacts of climate change in Nepal (Chaudhary 2020). Effective management of groundwater resources can be done by proper implementation of legal frameworks by the suitable institutions, proper programs for designing, monitoring and analysis of water level and water quality (Malla and Karki 2016). A survey conducted with users of the Panchakanya Irrigation System found that they 
wanted to contribute to conserving natural resources and water sources (Malla and Karki 2016). Thus, the policy and institutional reforms in Nepal's ongoing decentralization can give some hope for more inclusive governance, particularly through inclusion of marginalised groups in decision-making and ensuring access of water (White and Haapala 2018). Artificial process like construction of artificial ponds and tanks, short-term runoff accumulation, injection wells, water harvesting in ponds, flooding of uncultivated agricultural lands can be used to recharge natural source (O'Geen et al. 2015).

\section{Conclusion}

The Khageri Khola sub-watershed is facing the problem of the gradual decrease in water quantity and drying up of water sources due to climate variability (increasing temperature and erratic rainfall pattern), encroachment, land use conversion to settlements, urbanization, soil erosion, sedimentation, landslides, open water source, open grazing, temporary dumping site, invasion of invasive species and increasing population resulting dependency on natural resources. The sub-watershed's natural water sources are crucial for food security of the local communities as well as wildlife and bio-diversity conservation. To face the gradual decrease in water availability and different climate variability, conservation and management measures such as water source protection, bamboo plantation to decrease landslide, water collection tank construction, recharge pond construction have been adopted. Despite their active involvement, most people lack knowledge and awareness about climate change and its impact on water sources. Adaptation and management activities such as regular observation of sources, awareness programs on climate change, river bank protection, landslide treatment, land use restoration, rainwater harvesting, plantation in degraded and open area, and capital funding for water sources and integrated planning for conservation and management of the subwatershed need to be done. In addition, sustainable and adaptive water source management, upstream and downstream linkages in river system and inclusive water governance and facilitating platform for regular discussion on integrated water resource management should be reflected in government policy and programs.

\section{Acknowledgment}

We would like to convey our sincere gratitude to all the local communities, Government/Non-government organizations of Nepal, reviewer and personnel who provided their valuable time and shared their experiences during the study and Claire McMahon for English editing. We would also like to acknowledge WWF, Nepal for providing financial support for this study. 


\section{Literature Cited}

Burlakoti, C., and S. Karmacharya. 2004. Quantitative analysis of macrophytes of Beeshazar Tal, Chitwan, Nepal. Himalayan Journal of Sciences, 2. https://doi.org/10.3126/hjs.v2i3.229

Chapagain, P., M. Ghimire, and S. Shrestha. 2017. Status of natural springs in the Melamchi region of the Nepal Himalayas in the context of climate change. Environment, Development and Sustainability, 1-18. https://doi.org/10.1007/s10668-017-0036-4

Chaudhary, D., S. Maharjan, and A. V. Pallapu. 2020. The effect of climate change in the rural livelihood in Nepal: Case of Badarjhula of Chitwan district, Bagmati province, Nepal. IOSR Journal of Humanities and Social Science. 25. 21-30. 10.9790/0837-2510022130.

Dhakal, K. 2018. Landslide hazard zonation of Khageri watershed, Chitwan. Available online at Research Gate.

https://www.researchgate.net/publication/326894140; last accessed Jul.15, 2020

Dhakal, K. 2010. Land use change in Khageri watershed, Chitwan. The Third Pole: Journal of Geography Education, 51-56. https:/ / doi.org/10.3126/ttp.v8i0.11512

Dhungana, N., N. Silwal, S. Upadhaya, C. Khadka, S.K. Regmi, D. Joshi, and S. Adhikari. 2020. Rural coping and adaptation strategies for climate change by Himalayan communities in Nepal. Journal of Mountain Science, 17(6), 14621474. https://doi.org/10.1007/s11629-019-5616-3

Dhungana, S.M. 2019. Assessment of climate change impact and vulnerability to climate change among livestock holder in Chitwan district, Nepal. Available online at Research Gate. https://www.researchgate.net/publication/335377850; last accessed Jul.15, 2020.

DSCO. 2017. Integrated sub-watershed management plan of Khageri Khola subwatershed Chitwan district, Nepal. District Soil Conservation office, Makwanpur, Nepal

Dukes, J.S., and H.A. Mooney. 1999. Does global change increase the success of biological invaders? Trends in Ecology \& Evolution, 14(4), 135-139. https://doi.org/10.1016/S0169-5347 (98)01554-7

Flügel, W. A., S. Nepal, and A.B. Shrestha. 2018. Framework for upstreamdownstream linkages of land and water management in the Hindu Kush Himalaya (HKH) Region. Himalayan Adaptation, Water and Resilience (HIAWARE). Kathmandu, Nepal. https://lib.icimod.org/record/33880

Gurung, A., S. Adhikari, R. Chauhan, S. Thakuri, S. Nakarmi, S. Ghale, B. S. Dongol, and D. Rijal. 2019. Water crises in a water-rich country: Case studies from rural watersheds of Nepal's mid-hills. Water Policy, 21(4), 826-847.93 p. https://doi.org/10.2166/wp.2019.245 
Gurung, G. B., and D. Bhandari. 2009. Integrated approach to climate change adaptation. Journal of Forest and Livelihood, 8(1), 90-98.

ICIMOD. 2015. Reviving the drying springs; reinforcing social development and economic growth in the midhills of Nepal. International Center for Integrated Mountain Development. Kathmandu, Nepal. https:/ /lib.icimod.org/record/30276

IPCC. 2007. Climate change 2007: Synthesis report. Contribution of working groups I, II and III to the fourth assessment report of the intergovernmental panel on climate change. IPCC, Geneva, Switzerland, 104 pp https://www.ipcc.ch/site/assets/uploads/2018/02/ar4_syr.pdf

IPCC. 2014. Climate change 2014: Synthesis report. Contribution of working groups I, II and III to the fifth assessment report of the intergovernmental panel on climate change. IPCC, Geneva, Switzerland, $151 \mathrm{pp}$

Khan, S. A. M., M. S. Mondal, R. Sadda, and S. Gummadilli. 2013. Climatic trends and variability in south Asia: A case of four peri-urban locations. Hyderabad. Saciwaters and IDRC.

Khanal, S., and R. Kattel. 2017. Understanding farmers' perceptions and adaptations to climate change and variability in rice production at the Kaski and Chitwan Districts, Nepal. Asian Research Journal of Agriculture, 3, 1-12. https://doi.org/10.9734/ARJA/2017/29761

Lamichhane, B. R., and K. D. Awasthi. 2009. Changing climate in a mountain subwatershed in Nepal. Journal of Forests and Livelihood, 8(1), 99-105.

Macchi, M., A. M. Gurung, and B. Hoermann. 2015. Community perceptions and responses to climate variability and change in the Himalayas. Climate and Development, 7(5), 414-425. https:/ / doi.org/10.1080/17565529.2014.966046

Malla, R., and K. Karki. 2016. Groundwater environment in Chitwan, Nepal.

Groundwater Environment in Asian Cities (pp. 47-75). Elsevier. https://doi.org/10.1016/B978-0-12-803166-7.00004-0

Mallick, D., T. Dilshad, Z. Naznin, T.S.M. Hassan, A. Md. Syed, C.G. Goodrich, B.P. Udas, et al. 2019. Participatory assessment of multiple socio-economic drivers and climate stresses leading to differentiated vulnerabilities in the Hindu Kush Himalaya. International Centre for Integrated Mountain Development (ICIMOD). https://lib.icimod.org/record/34486

Merz, J., G. Nakarmi, and R. Weingartner. 2003. Potential solutions to water scarcity in the rural watersheds of Nepal's middle mountains. Mountain Research and Development, 23(1), 14-18. https:/ / doi.org/10.1659/0276-4741 (2003)023

MoE. 2010. National adaptation programme of action (NAPA) to climate change. Ministry of Environment. Kathmandu, Nepal.

MoFE. 2019. Climate change scenarios for Nepal for national adaptation plan (NAP). Ministry of Forests and Environment, Kathmandu, Nepal. 
MoFSC. 2015. Strategy and action plan 2015-2025, Terai Arc Landscape, Nepal. Ministry of Forests and Soil Conservation. Singha Durbar, Kathmandu, Nepal.

Nepal, S., A. Pandey, A.B. Shrestha, and A. Mukherji. 2018. Revisiting key questions regarding upstream-downstream linkages of land and water management in the Hindu Kush Himalaya (HKH) region. International Centre for Integrated Mountain Development (ICIMOD).

Nepal, S., W.A. Flügel, and A.B. Shrestha. 2014. Upstream-downstream linkages of hydrological processes in the Himalayan region. Ecological Processes, 3(1), 19. https://doi.org/10.1186/s13717-014-0019-4

Nicol, A., and N. Kaur. 2009. Adapting to climate change in the water sector, overseas development institute. ODI Background Notes, March, 1-8.

OECD. 2003. Development and climate change in Nepal. Focus on water resource and hydropower.1-64.

O'Geen, A., M. Saal, H. Dahlke, D. Doll, R. Elkins, A. Fulton, G. Fogg, et al. 2015. Soil suitability index identifies potential areas for groundwater banking on agricultural lands. California Agriculture, 69(2), 75-84.

Pandey, R., P. Kumar, K.M. Archie, A. K. Gupta, P. K. Joshi, D. Valente, and I. Petrosillo. 2018. Climate change adaptation in the western-Himalayas: Household level perspectives on impacts and barriers. Ecological Indicators, 84, 27-37. https://doi.org/10.1016/j.ecolind.2017.08.021

Paudel, P., and G. Kafle. 2012. Assessment and prioritization of community soil and water conservation measures for adaptation to climatic stresses in Makawanpur district of Nepal. Journal of Wetlands Ecology, 6, 44-51. https://doi.org/10.3126/jowe.v6i0.6997

Poudel, D. D., and T.W. Duex. 2017. Vanishing springs in Nepalese mountains: assessment of water sources, farmers' perceptions, and climate change adaptation. Mountain Research and Development, 37(1), 35. https:/ / doi.org/10.1659/MRD-JOURNAL-D-16-00039.1

Practical Action. 2009. Temporal and spatial variability of climate change over Nepal, 1976-2005. Practical Action Nepal Office.

Regmi, H. P., and S. Upendram. 2019. Farmers' perception and factors influencing adaptation in Rice cultivation at Chitwan, Nepal.Available online at Research Gate. https://www.researchgate.net/publication/335172317. Last accessed Jul.15, 2020.

Sharma, B., S. Nepal, D. Gyawali, G. Pokharel, S. Wahid, A. Mukherji, S. Acharya, and A. Shrestha. 2016. Springs, storage towers, and water conservation in the midhills of Nepal. Nepal Water Conservation Foundation and International Center for Mountain Development. ICIMOD Working Paper 2016/3. Kathmandu, Nepal https://doi.org/10.13140/RG.2.1.4142.4886 
Shrestha, K., A. Prakash, and B.R. Regmi. 2017. Irrigation system governance and climate change: study of Panchakanya irrigation system to understand its adaptive capacity and challenges [Unpublished Masters of Science in Environmental Management Thesis, School of Environmental Science and Management (SchEMS), Pokhara University]. https://hi-aware.org/wpcontent/uploads

Shukla, A., N. R. Joshi, G. Shivakoti, R. Poudel, and N. Shrestha. 1997. Dynamics in water rights and arbitration on water right conflicts: Cases of farmer managed irrigation systems from east Chitwan. Water Rights, Conflict and Policy.

Singh, S., S. M. T. Hassan, M. Hassan, and N. Bharti. 2019. Urbanisation and water insecurity in the Hindu Kush Himalaya: Insights from Bangladesh, India, Nepal and Pakistan. Water Policy, 22(S1), 9-32. https://doi.org/10.2166/wp.2019.215

Tambe, S., G. Kharel, M. L. Arrawatia, H. Kulkarni, K. Mahamuni, and A. K. Ganeriwala. 2012. Reviving dying springs: Climate change adaptation experiments from the Sikkim Himalaya. Mountain Research and Development, 32(1), 62-72. https://doi.org/10.1659/MRD-JOURNAL-D-11-00079.1

Thapa, K. 2005. Linkages among land, water and forest resources and their institutional dynamism in Chitwan district, Nepal. In Integrated Watershed Management: Studies and Experiences from Asia (p. 351). Asian Institute of Technology- AIT.

WBG. 2016. High and dry: climate change, water, and the economy. High and Dry: Climate Change, Water, and the Economy. https://doi.org/10.1596/k8517

White, P., and J. Haapala. 2018. Water security and social inclusion: local governance within the newly established rural municipalities in Nepal. New Angle: Nepal Journal of Social Science and Public Policy, 5, 29.

WHO. 2018. Drinking-Water. Available online at https://www.who.int/newsroom/fact-sheets/detail/drinking-water. Last accessed Jul.15, 2020.

WWF. 2006. An overview of glaciers, glacier retreat and its subsequent impacts in Nepal, India and China. WWF Nepal Program, 27-33.

Annex 1: Water source/stream, their status, importance and major issues

\begin{tabular}{|l|l|l|l|l|l|l|}
\hline S.N & $\begin{array}{l}\text { Name of } \\
\text { water source }\end{array}$ & $\begin{array}{l}\text { No of } \\
\text { water } \\
\text { source }\end{array}$ & Names of Water source & $\begin{array}{l}\text { Overall } \\
\text { status }\end{array}$ & Importance & Major issues \\
\hline 1 & $\begin{array}{l}\text { Khahare } \\
\text { Khola }\end{array}$ & 11 & $\begin{array}{l}\text { Lipegauda Muhan(1), } \\
\text { Simaldhaap Khanepani } \\
\text { Muhan(2), Amilipani } \\
\text { Muhan (3), } \\
\text { Dhaingungearan } \\
\text { Muhan }\end{array}$ & $\begin{array}{l}\text { Sufficient } \\
\text { to } \\
\text { moderate } \\
\text { amount } \\
\text { of water }\end{array}$ & $\begin{array}{l}\text { Main } \\
\text { source for } \\
\text { downstrea } \\
\text { m sources, } \\
\text { for } \\
\text { Muhan (5), Rani }\end{array}$ & $\begin{array}{l}\text { Encroachment, } \\
\text { illegal felling, } \\
\text { deforestation, } \\
\text { soil erosion, land } \\
\text { degradation }\end{array}$ \\
& & & & $\begin{array}{l}\text { water, } \\
\text { irrigation }\end{array}$ & \\
& & & & & \\
\end{tabular}




\begin{tabular}{|c|c|c|c|c|c|c|}
\hline S.N & \begin{tabular}{|l|} 
Name of \\
water source
\end{tabular} & $\begin{array}{l}\text { No of } \\
\text { water } \\
\text { source }\end{array}$ & Names of Water source & $\begin{array}{l}\text { Overall } \\
\text { status }\end{array}$ & Importance & Major issues \\
\hline & & & $\begin{array}{l}\text { Khola(6), Barne } \\
\text { Khola(7), Bagrang } \\
\text { Khola(8), Thulokali } \\
\text { Khola(9), Mulsyangdi } \\
\text { Khola(10) and Khageri } \\
\text { Khola(11) }\end{array}$ & & $\begin{array}{l}\text { and other } \\
\text { HH chores, } \\
\text { for } \\
\text { Livestock }\end{array}$ & \\
\hline 2 & Rani Khola & 3 & $\begin{array}{l}\text { Adheri Khola(12), } \\
\text { Bhoti Khola(13), } \\
\text { Khageri Khola(14) }\end{array}$ & $\begin{array}{l}\text { Moderate } \\
\text { to less } \\
\text { amount } \\
\text { of water }\end{array}$ & $\begin{array}{l}\text { For } \\
\text { wildlife, for } \\
\text { drinking } \\
\text { water and } \\
\text { for } \\
\text { livestock } \\
\text { while } \\
\text { grazing }\end{array}$ & Sedimentation \\
\hline 3 & BattarKhola & 10 & $\begin{array}{l}\text { Chisapanighumti(15), } \\
\text { Bung Khahare(16), } \\
\text { Farm ban Khola(17), } \\
\text { Bhimoli park Khola(18), } \\
\text { Mini rhino Tal(19), } \\
\text { Batter Khola(20), } \\
\text { PyauliPokhari(21), } \\
\text { Panchpokhari Tal(22), } \\
\text { Panchpokhari } \\
\text { Khola(23), and Khageri } \\
\text { Khola(24) }\end{array}$ & $\begin{array}{l}\text { Moderate } \\
\text { to less } \\
\text { amount } \\
\text { of water, } \\
\text { Dry and } \\
\text { after few } \\
\text { distance } \\
\text { marsh } \\
\text { land }\end{array}$ & $\begin{array}{l}\text { For } \\
\text { drinking } \\
\text { water and } \\
\text { irrigation, } \\
\text { for wildlife } \\
\text { and as an } \\
\text { aesthetic } \\
\text { value for a } \\
\text { park, } \\
\text { artificial } \\
\text { pond run } \\
\text { by solar } \\
\text { water } \\
\text { planning. }\end{array}$ & \begin{tabular}{|l} 
River bank \\
cutting, \\
sedimentation, \\
community \\
settlement, \\
urbanization, \\
open grazing, \\
open water \\
source, \\
Temporary \\
dumping site, \\
invasive species \\
like Bitter vine.
\end{tabular} \\
\hline 4 & ThangKhola & 17 & $\begin{array}{l}\text { Ranibel Khola (25), } \\
\text { Garedi Khola (26), } \\
\text { Sanosyangdi Khola (27), } \\
\text { Amarogaira Khola (28), } \\
\text { Devithaangaira } \\
\text { Khola(29), Bhoti } \\
\text { Khola(30), Kali } \\
\text { Khola(31), Kali Khola } \\
\text { Muhan(32), Amilipani } \\
\text { Muhan(33), Tirtire } \\
\text { Dhaara(34), Gangate } \\
\text { Khola(35), } \\
\text { Kyampadhaap } \\
\text { Pond(36), Kyampadhap } \\
\text { artificial Pond(37), Bhoti } \\
\text { Khola(38),Thang } \\
\text { Khola(39), } \\
\text { Gunumandre Ghol(40), } \\
\text { and Khageri Khola(41) }\end{array}$ & $\begin{array}{l}\text { Sufficient } \\
\text { to } \\
\text { moderate } \\
\text { amount } \\
\text { of water }\end{array}$ & $\begin{array}{l}\text { For } \\
\text { drinking } \\
\text { water, } \\
\text { irrigation } \\
\text { and } \\
\text { wildlife, } \\
\text { main } \\
\text { source for } \\
\text { other } \\
\text { source }\end{array}$ & \begin{tabular}{|l} 
Soil erosion, \\
encroachment \\
invasives pecies: \\
Banmara, Nilo \\
Gandhe and \\
Water Hyacinth, \\
sedimentation
\end{tabular} \\
\hline 5 & $\begin{array}{l}\text { Dhameli } \\
\text { Khola }\end{array}$ & 3 & $\begin{array}{l}\text { Dhameli Khola(42), } \\
\text { Kamini Ghat(43), } \\
\text { Khageri Khola(44) }\end{array}$ & $\begin{array}{l}\text { Medium } \\
\text { to Less } \\
\text { amount } \\
\text { of water. }\end{array}$ & $\begin{array}{l}\text { For } \\
\text { wildlife, } \\
\text { drinking } \\
\text { water }\end{array}$ & Sedimentation \\
\hline
\end{tabular}




\begin{tabular}{|l|l|l|l|l|l|l|}
\hline S.N & $\begin{array}{l}\text { Name of } \\
\text { water source }\end{array}$ & $\begin{array}{l}\text { No of } \\
\text { water } \\
\text { source }\end{array}$ & Names of Water source & $\begin{array}{l}\text { Overall } \\
\text { status }\end{array}$ & Importance & Major issues \\
\hline 6 & Rhino- Tal & 3 & $\begin{array}{l}\text { Rhino Tal(45), Tiger } \\
\text { Tal(46), and Khageri } \\
\text { Khola(47) }\end{array}$ & $\begin{array}{l}\text { Moderate } \\
\text { to less } \\
\text { amount } \\
\text { of water. }\end{array}$ & $\begin{array}{l}\text { Water } \\
\text { availability } \\
\text { for wildlife, } \\
\text { for } \\
\text { household } \\
\text { chores }\end{array}$ & $\begin{array}{l}\text { Invasive species } \\
\text { like Water } \\
\text { Hyacinth }\end{array}$ \\
\hline 7 & Bhoti Khola & 2 & $\begin{array}{l}\text { Bhoti Khola(48), and } \\
\text { Khageri Khola(49) }\end{array}$ & $\begin{array}{l}\text { Moderate } \\
\text { to less } \\
\text { amount } \\
\text { of water }\end{array}$ & $\begin{array}{l}\text { For } \\
\text { wildlife, for } \\
\text { drinking } \\
\text { water } \\
\text { availability }\end{array}$ & $\begin{array}{l}\text { Invasive species } \\
\text { like banmara, } \\
\text { Nilogandhe }\end{array}$ \\
\hline 8 & $\begin{array}{l}\text { Tikauli- } \\
\text { Kumal Tal }\end{array}$ & 7 & $\begin{array}{l}\text { Kumal Tal(50), Tikauli } \\
\text { Tal(51), Chepang } \\
\text { Tal(52), Ashok Tal(53), } \\
\text { Thulo Ghol(54), } \\
\text { Amasethi Tal(55), and } \\
\text { Sorhahajari Tal(56) }\end{array}$ & $\begin{array}{l}\text { Moderate } \\
\text { to Less } \\
\text { amount } \\
\text { to water }\end{array}$ & $\begin{array}{l}\text { Water for } \\
\text { wildlife } \\
\text { was made } \\
\text { artificially, } \\
\text { drinking } \\
\text { purpose, } \\
\text { irrigation }\end{array}$ & $\begin{array}{l}\text { Open source and } \\
\text { grazing, } \\
\text { community } \\
\text { settlement, } \\
\text { invasive species } \\
\text { like Water } \\
\text { hyacinth. }\end{array}$ \\
\hline
\end{tabular}

[Note: Number in the bracket of the water source represents location of water source in Figure 2. The sufficient to moderate amount of water that has been mentioned in status is according to the amount of water directly observed during the research field]

\section{Annex 2: Average maximum, minimum temperature and annual rainfall at Rampur station (DSCO, 2017)}

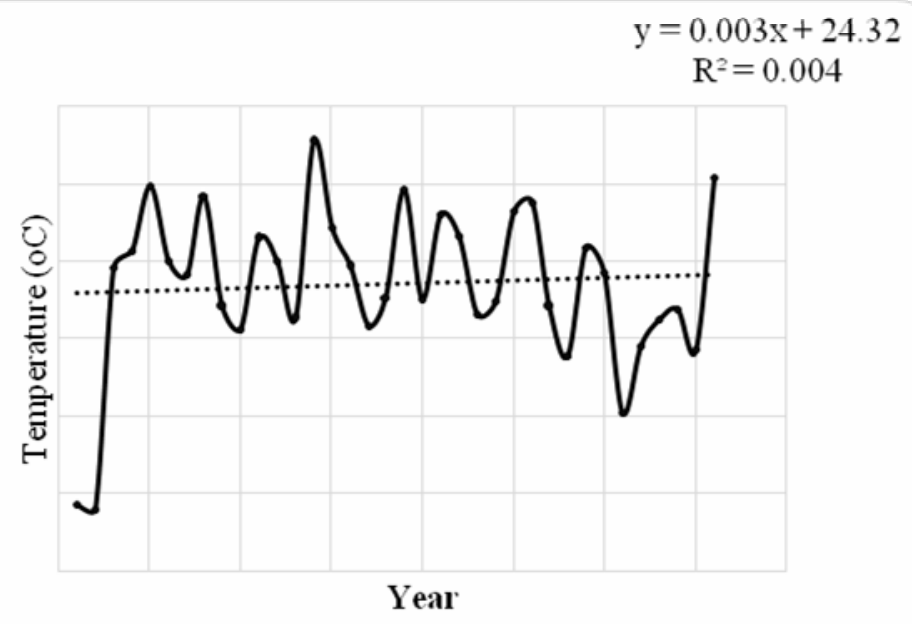

Figure 2: Average maximum temperature at Rampur station 


$$
\begin{gathered}
\mathrm{y}=0.020 \mathrm{x}-23.07 \\
\mathrm{R}^{2}=0.089
\end{gathered}
$$

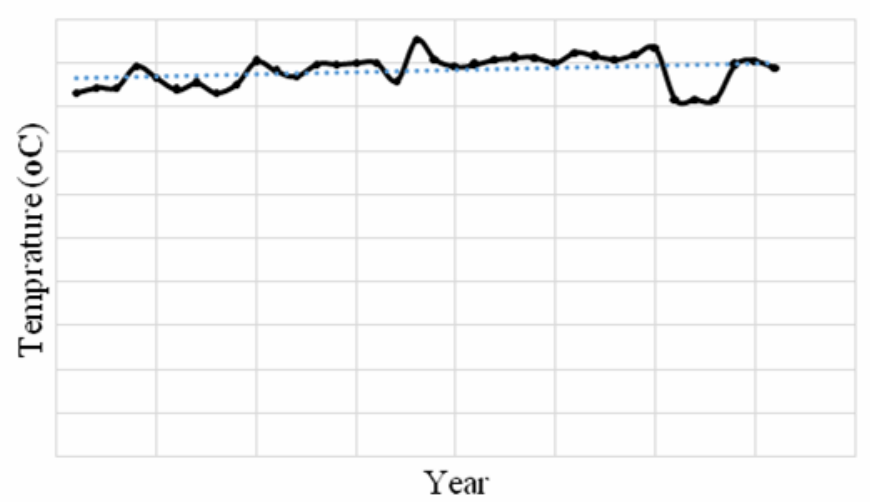

Figure 3: Average minimum temperature at Rampur station

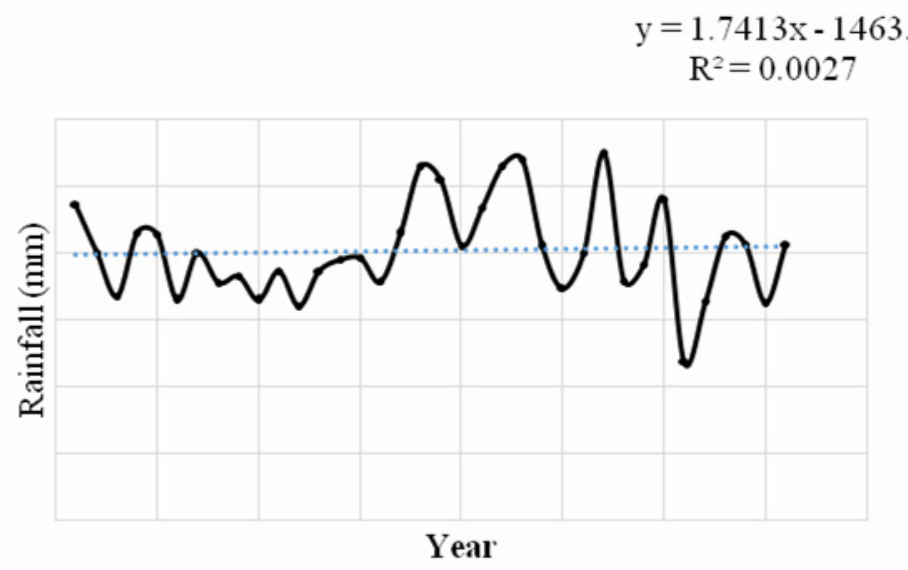

Figure 7: Annual rainfall at Rampur station 